Article

\title{
Media Activism as Movement? Collective Identity Formation in the World Forum of Free Media
}

\author{
Hilde C. Stephansen \\ Department of History, Sociology and Criminology, University of Westminster, London, W1B 2HW, UK; \\ E-Mail: h.stephansen@westminster.ac.uk
}

Submitted: 12 May 2017 | Accepted: 12 July 2017 | Published: 22 September 2017

\begin{abstract}
More than simply tools used by social movements to reach other substantive aims, media are increasingly becoming subjects of activism. This article contributes to advancing understanding of such media-focused activism through a case study of the World Forum of Free Media, a thematic forum for media activists and media advocacy organisations linked to the World Social Forum. Based on qualitative research conducted between 2008 and 2016-including participant observation, in-depth interviews and textual analysis - the article critically explores the extent to which the World Forum of Free Media can be considered a 'free media' movement in the making, and examines some of the challenges and contradictions that such a movement-building project entails. Drawing on social movement theory, specifically the concept of collective identity, it analyses efforts by forum organisers to mobilise a very diverse range of actors-from alternative media activists to policy- and advocacy NGOs - around a plural and inclusive 'free media' identity. While the World Forum of Free Media has to some extent succeeded in facilitating convergence around a set of core principles and ideas, it has so far struggled to develop a clear outwards-facing identity and mobilise a broad grassroots base.
\end{abstract}

\section{Keywords}

alternative media; collective identity; communication rights; FMML; media activism; media democracy movement; social movements; World Forum of Free Media; World Social Forum

\section{Issue}

This article is part of the issue "Acting on Media: Influencing, Shaping and (Re)Configuring the Fabric of Everyday Life", edited by Sigrid Kannengießer and Sebastian Kubitschko (University of Bremen, Germany).

(C) 2017 by the author; licensee Cogitatio (Lisbon, Portugal). This article is licensed under a Creative Commons Attribution 4.0 International License (CC BY).

\section{Introduction}

Much attention has been paid recently to the relationship between social movements and media, with research focusing on the implications of new media technologies for movement formation and protest trajectories. An important strand of this research has focused on the implications of new media technologies for processes of collective identity formation. A key argument has been that such technologies-social media in particular-have led to a reconfiguration of collective identity as conventionally understood within social movement studies (Bennett \& Segerberg, 2013; Milan, 2015a, 2015b). Less attention has been paid to the possibility of collective identity forming around media and technology as subjects of political contention. However, given the ubiquity and importance of media in contemporary society, and the rising prominence of media activism-understood here not just as activists' use of media to further other aims, but activism focused specifically on media and technology issues-it is important to examine processes of collective identity formation among media activists, and ask whether such activism might constitute a social movement in its own right. This is what this article sets out to do through a case study of the World Forum of Free Media (FMML, for the Portuguese Fórum Mundial de Mídia Livre), a thematic forum linked to the World Social Forum (WSF) that gathers civil society actors working on media and technology issues. What forms of collective identity are emerg- 
ing among activists involved in the FMML, and to what extent might it be considered an emergent 'free media' movement? Specifically, the article explores the tension between, on the one hand, efforts to develop a plural and inclusive definition of 'free media' that can enable convergence among a broad range of media activists, and, on the other, the need for a clear outwards-facing collective identity to facilitate external mobilisation.

The article begins with a brief outline of literature on the implications of new media technologies for collective identity formation, before moving on to discuss work that has conceptualised media activism as an emergent social movement, and outlining the understanding of collective identity adopted in this study. This is followed by an analysis of collective identity in the FMML, which considers the implications of the plural and inclusive definition of 'free media' that organisers and participants have developed. The findings presented here are based on qualitative research conducted between 2008 and 2016, which included participant observation at the FMML and WSF in 2009, 2011 and 2013; online ethnography of the 2016 FMML; eleven in-depth interviews with FMML participants conducted face-to-face and via Skype, in 2013 and 2016 respectively; and an analysis of the World Charter of Free Media (World Forum of Free Media, 2015). The analysis presented here draws on a larger research project on media activism in the WSF (see Stephansen, 2013a, 2013b, 2016).

\section{Movements, Media and Collective Identity}

A key concept in social movement studies, collective identity has been understood as central to the 'emergence, trajectories, and impacts' of movements (Polletta \& Jasper, 2001, p. 281). In very basic terms, it may be defined as a shared sense of 'we-ness' and collective agency (Snow, 2001); however, there is no single consensual definition (Flesher Fominaya, 2010). While some define collective identity in terms of individuals' 'cognitive, moral and emotional connection' to a broader collective (Polletta \& Jasper, 2001, p. 285), others have emphasised its interactive and shared character as a group's definition of its place within a wider social context (Melucci, 1995, 1996; Snow, 2001; Taylor \& Whittier, 1992). Scholars interested in the relationship between social movements and media have explored the consequences of new communications technologies for collective identity formation in contemporary movements. In its early days, the internet was associated with networked forms of collective action based on ideals of openness, fluidity and the co-existence of multiple identities (della Porta, 2005; Juris, 2008). While many celebrated the ability of this networked politics to bring together a 'movement of movements' against neoliberal globalisation, others expressed concerns about the capacity of networks based on 'thin' ideological ties to support a coherent collective identity (Bennett, 2004). Similar concerns have been mooted in relation to the rise of web 2.0 technologies. Bennett and
Segerberg's (2013) concept of 'connective action' highlights a shift, driven by the rise of social media, towards more individualised and personalised forms of activism that raise questions about the feasibility and necessity of collective identity as traditionally defined. Similarly, Milan's notion of 'cloud protesting' highlights how a politics of visibility, in which subjective experience is central, has 'partially replaced the politics of identity typical of social movements' (2015a, p. 887). Others, meanwhile, have explored empirical instances of social media use to show how collective identity is produced interactively through activists' communication practices (e.g. Kavada, 2015; Treré, 2015).

Less attention has been paid to the possibility of collective identities forming around media and communication as issues in their own right. However, the growing ubiquity of media technologies, combined with increasing awareness among activists of their significance and of 'media-related injustice' (Milan, 2013), make it important to pay attention the imaginaries that form around such technologies (cf. Fotopoulou, 2017; Juris, 2008). Specifically, it is important to explore the potential for collective identity formation-and the emergence of a social movement-around media-related issues. A growing literature on mobilisations around media and technology issues has used the language of movement to describe such activism (e.g. Calabrese, 2004; Hackett \& Carroll, 2006; Milan, 2013; Padovani \& Calabrese, 2014; Stein, Kidd, \& Rodríguez, 2009). Two studies (Hackett \& Carroll, 2006; Milan, 2013) are notable for their in-depth examination of media activism from a social movement studies perspective, and include discussions of collective identity. Hackett and Carroll examine activism aimed at democratising existing media systems in the US, Canada and UK, and find that such activism is better understood as a nexus-'a point of articulation between movements' (2006, p. 199) - than itself a movement. They emphasise the social embeddedness of media activism within multiple other struggles, and suggest that this undercuts the basis for collective identity, as media activists tend to identify first and foremost with other movements. Milan, meanwhile, examines 'emancipatory communication practices' - 'ways of social organizing seeking to create alternatives to existing media and communication infrastructure' (2013, p. 9)-and arrives at a similar conclusion: media activism does not (yet) exhibit the characteristics of a fully-fledged social movement. She suggests that part of the reason for this is the absence of a shared collective identity among the diverse actors working on media and communications issues.

In brief, the formation of a shared collective identity-and by extension a social movement-around media and technology issues is hampered by media activism's embeddedness in other social struggles and the diversity of the actors involved. The diffuseness of the media field and the ubiquity of media technologies mean that media activists operate on multiple fronts. One schism exists between activists focused on reforming ex- 
isting media systems and activists concerned with the creation of alternatives. But there are also important differences within each of these sectors. Milan finds considerable differences between two groups of emancipatory communication activists-community radio producers and radical tech activists-in terms of collective identity and ideological orientation. Hackett and Carroll identify several competing framings of the media's democratic deficit among media reform activists: a liberal 'free press, freedom of speech' frame; a 'media democratisation' frame that offers a more radical democratic vision of public communication; a 'right to communicate' frame grounded in human rights and development discourse; a 'mental and cultural environment' frame that emphasises the damaging effects of media commercialism; and a more radical 'media justice' frame, which positions media activism as part of broader social justice struggles against capitalism, racism and patriarchy (2006, pp. 78-79). All of this means that actors in the media democracy field tend to operate in isolation from each other, with only periodic and short-term collaborations (Hackett \& Carroll, 2006; Milan, 2013).

The formation of a social movement focused on media and technology issues seems to depend, then, on the diverse range of actors who operate in this field being brought together on a more permanent basis-and on the ability of these actors to develop a shared collective identity capable of bridging different frames and ideological orientations. The FMML is an interesting test case in this respect, because one of its aims has been precisely to provide a forum in which a diverse range of media activists can come together around a shared definition of 'free media'. In what follows, I explore collective identity formation in the FMML and some of the difficulties this involves. In doing so, I draw on an understanding of collective identity as both a process and a product, the former focusing on the 'shared meanings, experiences and reciprocal emotional ties as experienced by movement actors themselves through their interaction with each other' and the latter referring to 'a perception of shared attributes, goals and interests' that is accessible to movement insiders and outsiders alike (Flesher Fominaya, 2010 , p. 397). My focus on the process aspect is guided by Melucci's definition of collective identity as 'an interactive and shared definition produced by a number of individuals (or groups at a more complex level) concerning the orientations of their action and the field of opportunities and constraints in which such action is to take place' (1996, p. 70). This enables an understanding of collective identity as an ongoing internal process of knowledge production, involving a diversity of actors, about a movement's aims and the broader context in which it operates. My analysis of the product dimension draws on the framing perspective in social movement theory (e.g. Benford \& Snow, 2000; Johnston \& Noakes, 2005) to explore how 'free media' are framed by the FMML. As 'snapshots' that evoke shared principles and goals, define opponents, and outline strategies, frames are key to a movement's collective identity in the product sense. I draw here on this dual process/product definition to explore tensions arising from the plural and open-ended nature of internal processes of collective identity formation within the FMML and the difficulties this poses for the creation of a clearly defined outwards-facing collective identity.

\section{The FMML}

The FMML was first held in conjunction with the WSF 2009 in Belém, Brazil, having emerged out of a longer history of media activism within the WSF. Since its inception in 2001, the WSF has provided a space for media activists from around the world to come together, exchange knowledge and experiences, and produce alternative media coverage of the forum. At each WSF, activists have set up dedicated spaces for alternative media. Although their main purpose was initially to facilitate the production of alternative media content, these spaces also encouraged political debate, and activists soon began working to put media and communication issues on the agenda of the WSF. Media and communication first appeared as a thematic axis at the WSF 2003 (Milan, 2013, p. 36) and since then media activists have organised seminars and workshops at every WSF to discuss issues ranging from censorship and repression to community media, internet governance and public service broadcasting. The FMML has emerged out of this process. Following the first FMML in 2009, activists organised a series of seminars at the WSF 2011 in Dakar, which culminated in an Assembly on the Right to Communication. A second FMML was held in Rio de Janeiro in 2012, in conjunction with the Rio +20 People's Summit, followed by the third and fourth FMML in 2013 and 2015, both held in Tunis alongside the WSF. The fifth FMML was held in August 2016 in Montreal, again as part of the WSF.

As it has travelled to different locations, the FMML has brought together a range of organisations and groups from different parts of the world, and enabled participants to begin building transnational networks based on a sense of solidarity and shared struggle. For media activists who have been involved in the WSF process since its early days, the development of the FMML has been accompanied by a shift in their sense of identity from alternative media producers to participants in a movement focused on media and communication. As Bia Barbosa, who represents the Brazilian advocacy group Intervozes on the FMML's international organising committee, explained:

Since the beginning of the World Social Forum...we 've been trying to show communication rights and freedom of expression as a subject..., not only as a way to cover the WSF but as a thing itself....At the beginning of the WSF in 2001 we couldn't talk about a communication movement. We were alternative media, people that produced. Now we can talk about a movement. (interview with author, 2013) 
This narrative and language of 'movement' is also present in the documents of the FMML. The World Charter of Free Media states: 'Our network of activists...has evolved into an organized movement for freedom of expression and the fight for another form of communication' (World Forum of Free Media, 2015).

There is a certain performative quality to this statement-declaring the existence of a movement arguably also helps bring it into being. But such a claim needs to be problematised rather than taken at face value. While not the only defining feature of a social movement, the concept of collective identity provides a useful lens for exploring the extent to which it is possible to talk of a 'free media' movement. For Melucci and others in the social constructivist tradition, the process of collective identity formation is precisely what makes a social movement. For scholars in the resource mobilisation tradition, a clear outwards-facing collective identity is essential to a movement's ability to mobilise. In what follows, I explore these internal and external aspects of collective identity, and the tension between them, in the context of the FMML.

\section{Collective Identity Formation in the FMML}

Alongside face-to-face gatherings, which have enabled FMML participants to begin to recognise each other as part of a collective, the creation of documents expressing shared positions has been an important driver in the development of collective identity. Each FMML has culminated in an assembly that has issued a joint declaration, and the World Charter of Free Media was adopted in 2015, following a two-year process of consultation and debate through online forums and face-to-face meetings. Negotiating and agreeing the Charter was conceived explicitly by organisers as a process of collective identity formation. As Bia Barbosa suggested at the beginning of the process:

I think this charter is going to help us because...it's the same as the World Social Forum charter. Do you agree with that? Ok, so you can be with us. So I think this is going to help us to define and identify ourselves. (interview with author, 2013)

Modelling the FMML on the idea of the WSF as an 'open space' (Whitaker, 2008), accessible to anyone who agrees with its basic principles of opposition to neoliberalism and all forms of discrimination, organisers have sought to attract a broad range of organisations and groups working on media and technology issues. The Charter's definition of 'free media' incorporates a strikingly diverse range of actors:

We are communicators, activists, journalists, hackers, community media associations and free media, social movements and popular organizations. We are bloggers, audiovisual producers, free and open technol- ogy developers, associations, networks, unions, journalism schools, research centres on information and communication, and NGOs supporting access to information and communication. (World Forum of Free Media, 2015)

In certain respects, this definition of 'free media' is one that has emerged through the kind of interactive process of collective identity formation described by Melucci. It has depended on a process of mutual recognition among forum participants involving knowledge production about the shared characteristics, principles and aims of 'free media'. However, the development of this definition has also involved a deliberate effort by organisers to attract as wide a range of actors as possible. This drive for inclusivity has been informed by a recognition of the complexity of the contemporary media landscapes and the multiple forms of domination that arise from the growing power of states and corporations over communications media. As Erika Campelo, who until December 2016 represented the French NGO Ritimo on the FMML's international organising committee, explained: 'There are many fronts of struggle, many challenges. They can only be resolved if within the FMML we have organisations that work on different fronts' (interview with author, 2016, translated from Portuguese).

'Free media', then, has been adopted as an umbrella term to incorporate the broad range of actors that are in some way 'acting on media' (Kubitschko, 2017) today. However, the use of this term has not been unproblematic and there has been much discussion among organisers about its appropriateness. As Campelo reflected:

Why 'free media'? I think that there is already a question of definition in one language, regardless of which one. All the movements, we have our own particularities, we are not all exactly in agreement with a single definition....I think there are two obstacles: there's the obstacle of diversity of organisations that are involved in the process of free media, and the difficulty of language. (interview with author, 2013, translated from Portuguese)

Alongside the diversity of actors involved in the forum, linguistic differences complicate matters further. While 'free media' (médias libres) has resonance in French due to its connotations to the radios libres (free radio) movement of the 1970s, it does not resonate equally in all Francophone contexts. 'Free media' has little purchase among Anglophone activists, who are more familiar with terms like 'alternative' or 'independent' media, and while mídia livre/medios libres are more common in Portuguese and Spanish, they compete with similar terms. Such linguistic differences add another layer of complexity to a field of activism in which issues of terminology are already contentious (Couldry, 2009), and illustrate some of the specific challenges involved in building collective identity at a supranational scale. 
'Free media' is, in brief, an ambiguous term. In some respects, this ambiguity is useful. An empty signifier, 'free media' can absorb multiple meanings and thus has potential to generate identification among diverse actors. As one FMML participant, Mallory Knodel of the Association for Progressive Communication, argued, the ambiguity of the term 'free media' has been productive in the sense that it has facilitated conversations among diverse actors and enabled participants to recognise commonalities:

The definition gets stretched in interesting ways but I don't see a big pushback against that, people saying this isn't really free media, I think everybody kind of sees the connections and the definition just grows a bit to incorporate that analysis. (interview with author, 2016)

An inclusive and rather vague definition of 'free media', in other words, can facilitate conversation and knowledge production among forum participants, helping to generate chains of equivalence (Laclau \& Mouffe, 2001) among diverse actors. According to several organisers and participants, the FMML has enabled convergences between previously separate domains of media democracy activism, for example between policy advocacy groups and alternative media activists. However, while the vagueness of 'free media' has proved useful for enabling FMML participants to find commonalities between their struggles-in other words, for facilitating an internal process of collective identity formation-it has been less helpful in terms of developing a clear collective identity (in the product sense) that is accessible to outsiders. As Stéphane Couture, one of the local organisers of the $2016 \mathrm{FMML}$ and at the time a researcher at McGill University, explained:

The people we meet they see commonalities, they want to work together and continue discussing, but the people we don't meet they have difficulty understanding what is the goal of this..... It's difficult to find a discourse that will be able to join different communities that are not in our circles. (interview with author, 2016)

For example, as Couture explained, many hackers and radical tech activists who were invited to Montreal declined the invitation, believing the forum to be a conference about alternative media. At the same time, the forum has, according to organisers, struggled to attract alternative media producers, and most of the members of the FMML's international organising committee are advocacy and policy-oriented organisations.

This difficulty of 'finding a discourse' resonates with Hackett and Carroll's (2006) argument that media democracy activism faces specific challenges in terms of framing. In the context of the hegemony of free market liberalism, where a commercial media system has been naturalised, media and communication issues arguably have low 'issue salience'-even as media become ever more ubiquitous (Hackett \& Carroll, 2006). It is thus difficult to frame media-related injustice for a wider public. And, as discussed above, for activists working at a global scale, this lack of an effective frame through which to communicate with external publics is compounded by cultural, political, historical and linguistic differences.

A closer analysis of the World Charter of Free Media reveals some of the difficulties involved in developing a clear frame, and by extension a clear and coherent outwards-facing identity, covering the multiple issues and actors designated by the term 'free media'. The Charter can be read as a composite of the different understandings of 'free media' that exist among forum participants - the product of a process aimed at developing a relatively clear statement of shared principles while remaining inclusive. The result is a document that brings together several framings of 'free media', which can be traced to different historical and political trajectories. The most prominent of these is a right to communicate frame (cf. Hackett \& Carroll, 2006): the Charter references article 19 of the Universal Declaration of Human Rights on freedom of expression, and principle 1 reads 'We affirm that freedom of expression for everyone, the right to information and communication, and free access to knowledge are fundamental human rights'. Also prominent is a democracy frame, which emphasises the fundamental importance of free media for the proper functioning of democracy: principle 2 affirms that 'democratic information and communication is a fundamental condition in exercising democracy'. Included within this frame is also the notion that media should support pluralism and serve the general, public interest, as opposed to the narrow interests of commercial or state actors. As Hackett and Carroll (2006) also found, these are frames that circulate widely in the field of democratic media activism. The right to communicate frame has figured prominently in previous international mobilisations around media and communications issues, such as the Communication Rights in the Information Society campaign in the early 2000s and the New World Information and Communication Order debates in the 1970s and 1980s. Given the composition of the FMML organising committee, which strongly features policy-, development- and international solidarity NGOs, the prominence of these frames is not surprising.

Also present in the Charter, however, is what might be referred to as a cultural diversity frame. The Charter emphasises the importance of respecting the 'cultures, memories, histories and identities of the peoples of the world', stating that free media acknowledge the 'diversity of imaginations, identities and cultural expressions' and highlight 'other ways of living, other representations of the world'. This emphasis on respect for diversity is closely linked to a transformative communication frame, which emphasises the pedagogical role that free media 
play in supporting intercultural dialogue, co-operation and mutual understanding: 'We practice new forms of human communication that are intercultural, horizontal, non-violent, open, decentralized, transparent, inclusive and shared'. The presence of these frames is testament to the FMML's close links to the WSF, within which ideals of horizontality, intercultural dialogue and respect for epistemic plurality have featured strongly. Finally, it is also possible to detect a social justice frame: a paragraph in the Charter affirms that 'our struggles are an essential part of the fight for human rights and the struggle against colonialism, occupation, patriarchy, sexism, racism, neoliberalism and all forms of oppression and fundamentalism'.

The presence of these different frames within the Charter is a consequence of efforts to develop a comprehensive statement that is inclusive of the numerous perspectives on free media that circulate within the FMML. While it may be true, as Bia Barbosa affirmed, that 'we were able to write a definition that everybody feels comfortable with' (interview with author, 2016), the Charter also reflects broader political differences within the FMML. Although multiple frames are present within the Charter, they do not occupy an equal position: the focus on communication rights is more prominent than the social justice frame. While the embeddedness of media activism within broader social justice struggles is acknowledged in the passage quoted above, this more radical language of struggle against oppression does not feature prominently in the rest of the Charter. Notable for its absence is any reference to capitalism or anti-capitalist struggles. While the Charter does discuss questions of political economy, it does so primarily in terms of cultural and linguistic commodification and homogenisation by the mainstream media, and counterposes the 'commercial values' of the mainstream media system to 'general interests and social values'. Beyond highlighting media activism's embeddedness in other struggles, the Charter does not really develop an analysis of the media's role in sustaining structures of oppression.

The dominance of a rights frame and relative marginalisation of a more radical social justice frame may have implications in terms of mobilisation. An outwards-facing collective identity focused on communication rights and democracy may be useful for mobilising institutional actors such as NGOs working on policy- and governance issues, and for some organisers this is a key aim. At the same time, the forum's difficulties in attracting alternative media producers and radical tech activists may be linked to the relative absence of a more radical social justice discourse. A key challenge is therefore to develop an outwards-facing collective identity that resonates with these constituencies. This, however, might run the risk of distancing more institutionalised actors such as development- and policy-oriented NGOs. As Stéphane Couture put it, 'we have a lot of discussion about communication rights and freedom of expression and it would be good to be more political in our discourse, but at the same time we might lose people' (interview with author, 2016). The dilemma that the FMML faces in terms of whether to develop a clearer and more political outwards-facing identity, which might help mobilise grassroots support among radical media activists, or to retain a more inclusive and moderate identity that arguably has wider appeal, is one that it shares with other activist networks. As in the case of the WSF, as well as more recent mobilisations like Occupy, openness and inclusivity facilitates connections and knowledge production among diverse actors, but the absence of a clear outwards-facing collective identity raises questions about the effectiveness of such activist formations.

\section{Discussion}

This article has been informed by the underlying question of whether the FMML can be considered an emergent social movement focused on media and technology issues. While it is possible to identify convergence around a plural definition of 'free media' and agreement about some core principles, it is unclear, given the diversity of actors involved and the very different contexts in which they operate, whether it is possible to construct a movement with a strong collective identity and unified strategy. Another question is whether this would be desirable. It is difficult to envisage a global-scale movement in any area of activism, let alone 'free media', that would not inevitably exclude certain actors and perspectives due to the impossibility of constructing a single collective identity that would resonate equally in different geographical, cultural and political contexts. Media activists in different parts of the world operate in very different conditions and face very different challenges, and it is important to acknowledge and respect these differences. The openness of the 'free media' identity arguably allows media activists in different contexts to adapt it to their local realities while maintaining a sense of connectedness to global struggles.

The question of whether 'free media' should become a unified movement based on a clearly delineated collective identity is further complicated by the embeddedness of media activism within broader social struggles (cf. Hackett \& Carroll, 2006). A challenge that is quite peculiar to the field of media activism is that it does not have an identity-based constituency or base in the same way as other social movements do. Media activists are rarely only media activists - they often come from a background in other movements and have multiple identifications (Hackett \& Carroll, 2006). Unsurprisingly, there is therefore no clear consensus among FMML participants on the question of 'are we part of social movements or are we ourselves a social movement?' (Mallory Knodel, interview with author, 2016). The two orientations are not necessarily mutually exclusive, and many activists operate on both fronts without experiencing this as a contradiction. However, there can be instances where principles associated with 'free media' come into conflict with 
other commitments. For example, as Mallory Knodel suggested, a commitment to non-corporate communication tools may come into conflict with a commitment to 'giving voice' to marginalised groups who lack the technical skills to use such tools (interview with author, 2016). At the FMML in Montreal, there was a controversy about whether the FMML, as a collective, should sign up to the Boycott, Divestment and Sanctions (BDS) campaign against the Israeli occupation of Palestine. A key question here-which was not resolved in Montreal-was whether the FMML's stated opposition to colonialism and occupation extended to support for the Palestinian struggle. These brief examples underline how an analysis of media and technology-related issues cannot be separated from an analysis of broader structures of domination. Questions such as that of whether to support BDS cannot be resolved through an analysis of media and technology issues in isolation-it requires an analysis of the intersections of media activism with other social justice struggles. An understanding of media activism as a movement in its own right arguably risks losing sight of these intersections.

\section{Conclusion}

This article has explored collective identity formation within the FMML, considering the extent to which it can be conceptualised as an emergent 'free media' movement. Operating with an understanding of collective identity as both process and product (Flesher Fominaya, 2010), it has found that the plural and inclusive definition of 'free media' developed by the FMML has been useful for facilitating internal processes of collective identity formation but less effective when it comes to external mobilisation. This is both due to the varying meanings associated with 'free media' in different linguistic and cultural contexts, and the co-existence of multiple contending frames within the FMML. It is therefore unclear whether the FMML can develop into a global-scale 'free media' movement. However, given the diversity of actors involved, the complexity of the issues they address, and the embeddedness of media activism within broader struggles, such a movement would not necessarily be desirable. The FMML is still at an early stage and at this conjuncture its most important function is arguably to facilitate ongoing processes of collective identity formation among participants. This, importantly, involves not simply processes by which individuals come to identify with a broader collective, but complex processes of knowledge production concerning shared aims, principles and the broader social, economic and political contexts in which 'free media' operate. This article has identified a possible tension within the FMML between a right to communicate frame and a more radical social justice frame, and argued that while the former resonates with policy- and advocacy NGOs, the relative marginalisation of the latter might be an obstacle to mobilising grassroots support among radical tech activists, alternative media producers and social movement communicators. Although it may not be desirable for the FMML to abandon one of these frames in favour of the other, a more explicitly political analysis of the links between 'free media' and other social justice struggles would be helpful in terms of establishing a clearer sense of shared principles. Given the centrality of media technologies to the functioning of contemporary capitalism (Dean, 2009) and the media's role in maintaining other structures of oppression, such an analysis is both urgent and important.

\section{Acknowledgments}

The research presented in this article was supported by the Centre for the Study of Global Media and Democracy at Goldsmiths, University of London (2013) and the University of Westminster (2016). It forms part of a larger research project about media activism in the World Social Forum, partly funded by an ESRC doctoral studentship (ES/F022557/1).

\section{Conflict of Interests}

The author declares no conflict of interests.

\section{References}

Benford, R. D., \& Snow, D. A. (2000). Framing processes and social movements. Annual Review of Sociology, 26, 611-639.

Bennett, W. L. (2004). Communicating global activism: Strengths and vulnerabilities of networked politics. In W. van de Donk, B. D. Loader, P. G. Nixon, \& D. Rucht (Eds.), Cyberprotest: New media, citizens and social movements (pp. 123-146). London: Routledge.

Bennett, W. L., \& Segerberg, A. (2013). The logic of connective action: Digital media and the personalization of contentious politics. Cambridge: Cambridge University Press.

Calabrese, A. (2004). The promise of a civil society: A global movement for communication rights. Continuum, 18(3), 317-329.

Couldry, N. (2009). Introduction to section 1. In C. Rodríguez, D. Kidd, \& L. Stein (Eds.), Making our media: Global initiatives toward a democratic public sphere. Vol. 1: Creating new communication spaces. Cresskill, NJ: Hampton Press.

Dean, J. (2009). Democracy and other neoliberal fantasies. Durham, NC: Duke University Press.

della Porta, D. (2005). Multiple belongings, tolerant identities, and the construction of "another politics": Between the European Social Forum and the local social fora. In D. Della Porta \& S. Tarrow (Eds.), Transnational protest and global activism: An introduction (pp. 175-202). Oxford: Rowman \& Littlefield.

Flesher Fominaya, C. (2010). Collective identity in social movements: Central concepts and debates. Sociology Compass, 4(6), 393-404. 
Fotopoulou, A. (2017). Feminist activism and digital networks: Between empowerment and vulnerability. Basingstoke: Palgrave Macmillan.

Hackett, R. A., \& Carroll, W. K. (2006). Remaking media: The struggle to democratize public communication. London: Routledge.

Johnston, H., \& Noakes, J. A. (2005). Frames of protest: Social movements and the framing perspective. Lanham: Rowman \& Littlefield Publishers.

Juris, J. S. (2008). Networking futures: The movements against corporate globalization. Durham, NC, and London: Duke University Press.

Kavada, A. (2015). Creating the collective: Social media, the Occupy movement and its constitution as a collective actor. Information, Communication \& Society, 18(8), 872-886.

Kubitschko, S. (2017). Acting on media technologies and infrastructures: Expanding the media as practice approach. Media, Culture \& Society. doi:10.1177/ 0163443717706068

Laclau, E., \& Mouffe, C. (2001). Hegemony and socialist strategy: Towards a radical democratic politics (2nd ed.). London: Verso.

Melucci, A. (1995). The process of collective identity. In H. Johnston \& B. Klandermans (Eds.), Social movements and culture (pp. 41-63). London: Routledge.

Melucci, A. (1996). Challenging codes: Collective action in the information age. Cambridge: Cambridge University Press.

Milan, S. (2013). Social movements and their technologies: Wiring social change. London: Palgrave Macmillan.

Milan, S. (2015a). From social movements to cloud protesting: The evolution of collective identity. Information, Communication \& Society, 18(8), 887-900.

Milan, S. (2015b). Mobilizing in times of social media: From a politics of identity to a politics of visibility. In L. Dencik \& O. Leistert (Eds.), Critical perspectives on social media and protest: Between control and emancipation (pp. 53-72). London: Rowman \& Littlefield.

Padovani, C., \& Calabrese, A. (Eds.). (2014). Communication rights and social justice: Historical accounts of transnational mobilizations. London: Palgrave MacMillan.

Polletta, F., \& Jasper, J. M. (2001). Collective identity and social movements. Annual Review of Sociology, 27, 283-305.

Snow, D. (2001). Collective identity and expressive forms. In N. J. Smelser \& P. B. Baltes (Eds.), International encyclopedia of the social and behavioural sciences (pp. 196-254). London: Elsevier Science.

Stein, L., Kidd, D., \& Rodríguez, C. (2009). Making our media: Global initiatives toward a democratic public sphere. Vol. 2: National and global movements for democratic communication. Cresskill, NJ: Hampton Press.

Stephansen, H. C. (2013a). Starting from the Amazon: Communication, knowledge and politics of place in the World Social Forum. Interface: A Journal for and About Social Movements, 5(1), 102-127.

Stephansen, H. C. (2013b). Connecting the peripheries: Networks, place and scale in the World Social Forum process. Journal of Postcolonial Writing, 49(5), 506-518.

Stephansen, H. C. (2016). Understanding citizen media as practice: Agents, processes, publics. In $\mathrm{M}$. Baker \& B. Blaagaard (Eds.), Citizen media and public spaces: Diverse expressions of citizenship and dissent (pp. 25-41). London: Routledge.

Taylor, V., \& Whittier, N. (1992). Collective identity in social movement communities: Lesbian feminist mobilization. In A. D. Morris \& C. M. Mueller (Eds.), Frontiers in social movement theory (pp. 104-29). London: Yale University Press.

Treré, E. (2015). Reclaiming, proclaiming, and maintaining collective identity in the \#YoSoy132 movement in Mexico. Information, Communication \& Society, 18(8), 901-915.

Whitaker, C. (2008). The World Social Forum as open space. In J. Sen \& P. Waterman (Eds.), World Social Forum: Challenging empires (2nd ed., pp. 81-93). London: Black Rose Books.

World Forum of Free Media. (2015). World Charter of Free Media. Retrieved from http://www.fmml.net/ spip.php?article146

\section{About the Author}

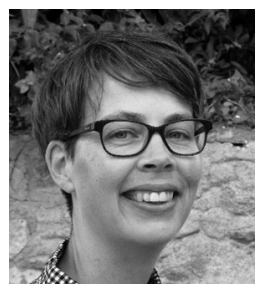

Hilde C. Stephansen is Lecturer in Sociology in the Department of History, Sociology and Criminology at the University of Westminster. Situated at the intersection of political sociology with media and communication studies, her research interests include media activism, citizen media, publics and public sphere theory, social movements and transnational activist networks. She is the author of several peer-reviewed articles in these areas, and the co-editor of Citizen Media and Practice (Routledge, forthcoming). 